\title{
Limnological description of the Tarelo lagoon (SW Spain).
}

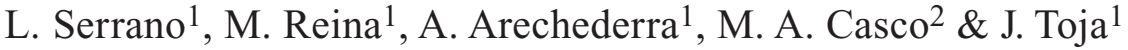 \\ ${ }^{1}$ Departamento de Biología Vegetal y Ecología. Universidad de Sevilla. Ap. 1095. 41080. Sevilla. Spain. \\ 2 P.C. Ficología. Museo de La Plata. Ap. 1900. La Plata. Argentina.
}

\begin{abstract}
The lagoon of Tarelo (SW, Spain) is a permanent aquatic system located near the estuary of the Guadalquivir River. The water quality of this lagoon was poor during the study period (January 2001-August 2002): the high water turbidity hindered the growth of submersed aquatic macrophytes and the bottom water was depleted of dissolved oxygen in spring-summer despite the mixing created by the wind. The concentration of planktonic chlorophyll $a$ ranged from 74.2 to $330.7 \mu \mathrm{g} 1^{-1}$ in the surface water and from 34.8 to $256.2 \mu \mathrm{g} \mathrm{l}^{-1}$ in the bottom water. The blooms of cyanobacteria $\left(>10^{6}\right.$ cells $\left.\mathrm{ml}^{-1}\right)$ were frequent and contributed to the generation of episodic anoxia in the water column. Consequently, the number of both planktonic and benthonic taxa were very low. Two taxa of cyanobacteria, Aphanocapsa holsatica and Microcystis sp., occurred with an average relative abundance $>30 \%$. The most commonly found taxa were Oscillatoria sp., Oocystis sp., Oscillatoria limnetica, Chroococcus sp. and Monoraphidium circinalle. Population explosions (>2000 ind $\left.1^{-1}\right)$ were common in rotifers such as Brachionus plicatilis and Keratella tropica. The density of Chironomus plumosus in the sediment surface declined abruptly when oxygen was scarce. The temporal variability of nutrient concentrations ranged from event-scale pulses to seasonal time scales. Nitrogen followed a seasonal pattern of loading in winter and depletion in summer, whereas the availability of o-P in the water oscillated in pulses. The concentration of o-P in the interstitial water of the sediment peaked intermittently during the study period and it was positively correlated with the concentration of o-P in the bottom-water $(\mathrm{r}=0.698, \mathrm{P}<0.05)$. On average, the concentrations of organic matter and Tot-P in the sediment were relatively low ( $7 \%$ and $456 \mu \mathrm{gDW}^{-1}$, respectively), and both variables were highly correlated $(\mathrm{r}=0.853, \mathrm{P}<0.01)$. The majority of the sediment $\mathrm{P}$ was organic, indicating the great contribution of the autochthonous production to the sediment load. It can be expected that the internal P loading will increase with time and lead the system to a higher trophic degree.
\end{abstract}

Keywords: eutrophication, water quality, P-fractionation, cyanobacteria, white-headed duck, Oxyura leucocephala.

\section{RESUMEN}

La laguna de Tarelo (SO España) es un sistema acuático permanente situado cerca del estuario del Río Guadalquivir. La calidad del agua de esta laguna fue pobre durante el período estudiado (enero 2001-agosto 2002): la elevada turbiedad del agua limitó el crecimiento de plantas acuáticas sumergidas y no se detectó oxígeno disuelto en el fondo de la columna de agua durante la primavera-verano a pesar de la mezcla generada por el viento. La concentración de clorofila planctónica osciló entre 74.2 y $330.7 \mu \mathrm{g} \mathrm{l}^{-1}$ en la superficie y, entre 34.8 y $256.2 \mu \mathrm{g} \mathrm{l}^{-1}$ en el fondo de la laguna. Las proliferaciones masivas de cianobacterias fueron frecuentes $\left(>10^{6}\right.$ cells $\left.\mathrm{ml}^{-1}\right)$ y contribuyeron a la aparición de episodios de anoxia en la columna de agua. En consecuencia, el número de taxa tanto en el plancton como en el bentos fue muy bajo. Dos cianobacterias, Aphanocapsa holsatica $y$ Microcystis sp., alcanzaron una abundancia relativa promedio $>30 \%$. Los taxa más comunes en el fitoplancton fueron: Oscillatoria $s p$., Oocystis $s p$., Oscillatoria limnetica, Chroococcus sp. y Monoraphidium circinalle. Las poblaciones de rotiferos como Brachionus plicatilis y Keratella tropica experimentaron explosiones de más de 2000 ind $l^{-1}$. La densidad de Chironomus plumosus en la superficie del sedimento disminuyó drásticamente a bajas concentraciones de oxígeno. La concentración de nutrientes mostró una amplia variabilidad temporal: desde patrones estacionales hasta pulsos intermitentes. El $N$ siguió un patrón estacional de enriquecimiento en invierno y desaparición en verano, mientras que la disponibilidad de o-P osciló en pulsos. La concentración de o-P en el agua intersticial del sedimento, que siguió una evolución de picos $y$ valles a lo largo del periodo de estudio, se correlacionó con la concentración de o- $P$ en el agua del fondo $(r=0.698, P<0.05)$. Las concentraciones promedio de materia orgánica y Tot- $P$ en el sedimento fueron relativamente bajas $(7 \%$ y $456 \mu g \mathrm{gDW}-1$, respectivamente) $y$, ambas variables se correlacionaron fuertemente $(r=0.853, P<0.01)$. La mayor parte del $P$ sedimentario era de composición orgánica, lo que indica la importancia de la producción autóctona en la carga de nutrientes del sedimento. Es esperable que la carga interna de P aumente en el tiempo elevando el nivel trofico de este sistema.

Palabras clave: eutrofización, calidad del agua, fraccionamiento de P, cianobacterias, malvasía, Oxyura leucocephala.

Limnetica 23(1-2): 1-10 (2004). DOI: 10.23818/limn.23.01

(C) Asociación Ibérica de Limnología, Madrid. Spain. ISSN: 0213-8409 


\section{INTRODUCTION}

The lagoon of Tarelo (SW, Spain) is a permanent aquatic system located at $3 \mathrm{~km}$ from the estuary of the Guadalquivir River in the limit of the village of Sanlúcar de Barrameda with the Doñana Natural Park. The bed of the lagoon was originated by excavation for the extraction of sand and other dry materials. The pit was eventually flooded through seepage from the estuary during winter 1989. Since then, it has become an important breeding site for the White-headed duck (Oxyura leucocephala). For this reason this site is under protection of the Doñana Natural Park. However, this lagoon is located in an agricultural area of intensive activity and it is fed by the riverbed aquifer of the Guadalquivir River, which has long been suffering a severe nitrate pollution (Navarro Alvargonzález et al., 1993). Consequently, a very high productivity can be expected in this lagoon that has changed from a system with a dense submersed macrophyte development to another dominated by phytoplankton in recent years.

The coastal lagoons are very dynamic systems, therefore assessing the scale of variation and the range of transitional stages they pass through are basic tools for their management (Comín et al., 1999). This study describes the limnology of the lagoon of Tarelo from January 2001 to August 2002 focusing on its water quality. The nutrient dynamics has been addressed in time and space by studying the changes in the vertical structure of the water column and its interaction with the sediment.

\section{MATERIAL AND METHODS}

The lagoon was sampled monthly between January 2001 and August 2002 at an open site (3-4 $\mathrm{m}$ deep) and a littoral site (1.5-2.5 m deep). A day-cycle sampling was performed in May and June 2001. Vertical profiles of temperature, dissolved oxygen and $\mathrm{pH}$ were measured in situ with a probe. The light compensation point was estimated as 2.7 times the depth of the Secchi
Disk (Margalef, 1983). Conductivity (ATC) was measured in the laboratory. Water samples were taken in duplicates from the surface and the bottom of the water column at both sites using an electrical bilge pump. Water was filtered through Whatman GF/C filters in the laboratory. Chlorophyll $a$ was extracted with methanol in 3 replicates per sample (Marker et al., 1980) and its concentration was calculated using Talling \& Driver's formula (Vollenweider, 1969). The following chemical concentrations were measured in the water samples in 2-3 replicates: total suspended solids (gravimetry), organic suspended solids (gravimetry after ignition at $450{ }^{\circ} \mathrm{C}, 5 \mathrm{~h}$ ), $\mathrm{Cl}^{-}$(APHA, 1985), $\mathrm{SO}_{4}^{2-}$ (Rodier, 1981), total alkalinity (Golterman et al., 1978), $\mathrm{NO}_{2}^{-}$ (Strickland \& Parsons, 1972), $\mathrm{NO}_{3}{ }^{-}$(Golterman, 1991), o-P (Murphy \& Riley, 1962), $\mathrm{NH}_{4}^{+}$by nesslerization (Rodier, 1981), and total phosphorus (Tot-P) after acid digestion (De Groot \& Golterman, 1990). Sediments were collected with an Ekman-Birge bottom sampler. In the laboratory, sediments were not treated (neither dried nor frozen) and stored at $4{ }^{\circ} \mathrm{C}$. The concentration of organic matter in the sediment was estimated in 3-4 replicates by loss on ignition $\left(450{ }^{\circ} \mathrm{C}, 5 \mathrm{~h}\right)$. The Tot-P concentration in the sediment samples was measured after acid digestion (De Groot \& Golterman, 1990) of the ignited sediment. The concentration of total $\mathrm{N}$ in the sediment was estimated as the concentration of $\mathrm{NH}_{4}^{+}$measured after nesslerization of the digested sediment. The interstitial water was obtained by centrifugation (12 000 r.p.m., 15 $\mathrm{min}$ ) and the concentration of o-P was measured as before. The P-fractionation of the sediment was performed in duplicates of a sample collected in May 2001 from the open site. A portion of the sediment sample was sieved through a nytal mesh of $0.1 \mathrm{~mm}$ pore size (fine sediment). Both the fine sediment and the unsieved sediment (total sediment) were fractionated by sequential extraction with chelating compounds following the EDTA's method (Golterman, 1996).

Lugol preserved samples of phytoplankton were observed according to the Utermöhl's (1958) technique for enumeration. Zooplankton 
samples were collected by filtering 5-10 1 of water through a nytal mesh of $63 \mathrm{~mm}$ pore size and preserved in $4 \%$ formaldehyde. The benthic invertebrates were collected with an EkmanBirge bottom sampler of $144 \mathrm{~cm}^{2}$ of surface and preserved in $70 \%$ ethanol for further examination with a binocular microscope.

Rainfall data was obtained from the meteorological station of "Palacio de Doñana" (RBD-CSIC).

\section{RESULTS}

The water depth ranged from 3 to $4 \mathrm{~m}$ at the open site during the study period. The electrical conductivity (ATC) ranged from 9.4 to $13.5 \mathrm{mS}$ $\mathrm{cm}^{-1}$. Water was rich in $\mathrm{Cl}^{-}$and $\mathrm{SO}_{4}^{2-}$ and ranged from 125 to 137 meq $1^{-1}$ and from 42 to $47 \mathrm{meq}^{-1}$, respectively, whereas total alkalinity was much lower (2-3 meq $\left.\mathrm{l}^{-1}\right)$.

The vertical profile of temperature changed within a very narrow range from the top to the bottom of the water column $\left(0.5-1.5{ }^{\circ} \mathrm{C}\right.$ in winter and $3-5.5{ }^{\circ} \mathrm{C}$ in summer). A weak thermal stratification developed during the day in summer, suggesting that this lagoon was polymictic.

The concentration of dissolved oxygen changed widely across the water column during the study period (Table 1 and Figure 1). The concentration

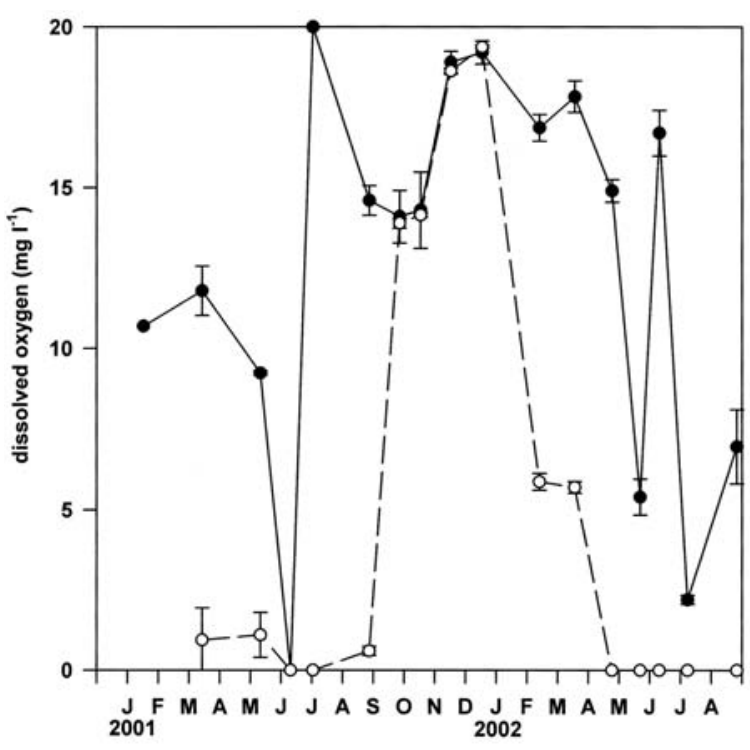

Figure 1. Concentration of dissolved oxygen in the surface (solid line) and bottom water (dashed line) at the open site during the study period. Mean $\pm \mathrm{SD}$. Concentración de oxígeno disuelto en la superficie (línea continua) y el fondo (línea discontinua) del centro durante el periodo de estudio.

of dissolved oxygen in the surface water was always higher than in the bottom water, except for an episodic anoxia in June 2001 when both concentrations were zero, or when the whole water column was oxygenated due to strong winds (September-December 2001). Consequently, the

Table 1. Minimum and maximum values of several variables in the surface and bottom of the water column at the open site during the study period (January-December 2001 and January-August 2002). Valores mínimos y máximos de diversas variables en la superficie y el fondo de la columna de agua durante el período de estudio.

\begin{tabular}{|c|c|c|c|c|}
\hline & \multicolumn{2}{|c|}{2001} & \multicolumn{2}{|c|}{2002} \\
\hline & Surface & Bottom & Surface & Bottom \\
\hline Temperature $\left({ }^{\circ} \mathrm{C}\right)$ & $14.4-28.5$ & $14.4-27.3$ & $13.2-26.2$ & $11.9-25.0$ \\
\hline D.O. $\left(\mathrm{mg} \mathrm{l}^{-1}\right)$ & $0.0-20.0$ & $0.0-19.4$ & $2.2-19.2$ & $0-5.9$ \\
\hline $\mathrm{pH}$ & $6.3-9.6$ & $6.3-9.1$ & $5.6-9.5$ & $5.5-8.8$ \\
\hline Chl $a\left(\mu \mathrm{g} \mathrm{l}^{-1}\right)$ & $74.2-226.6$ & $34.8-174.5$ & $115.2-330.7$ & $105.6-256.2$ \\
\hline T.S.S. $\left(\mathrm{mg} \mathrm{l}^{-1}\right)$ & $25.6-60.5$ & $24.9-56.5$ & $49.0-238.3$ & $111.7-200.0$ \\
\hline $\mathrm{NO}_{3}^{-}(\mathrm{mM})$ & $0.0-20.3$ & $0.0-11.4$ & $0.0-8.0$ & $0.0-1.6$ \\
\hline $\mathrm{NO}_{2}-(\mu \mathrm{M})$ & $6.4-946.6$ & $13.4-961.3$ & $7.4-312.0$ & $3.5-98.8$ \\
\hline $\mathrm{NH}_{4}^{+}(\mathrm{mM})$ & $0.1-2.2$ & $0.1-2.7$ & $0.4-3.0$ & $0.7-5.3$ \\
\hline o-P $\left(\mu \mathrm{g} \mathrm{l}^{-1}\right)$ & $1.8-97.4$ & $3.7-150.1$ & $7.1-48.5$ & $6.5-234.9$ \\
\hline Tot-P $\left(\mu \mathrm{g} 1^{-1}\right)$ & $101.6-600.0$ & $135.3-666.6$ & $155.9-317.6$ & $216.3-528.5$ \\
\hline DIN/Tot-P & $46.7-1281.6$ & $42.8-936.2$ & $73.8-784.0$ & $59.5-215.7$ \\
\hline
\end{tabular}




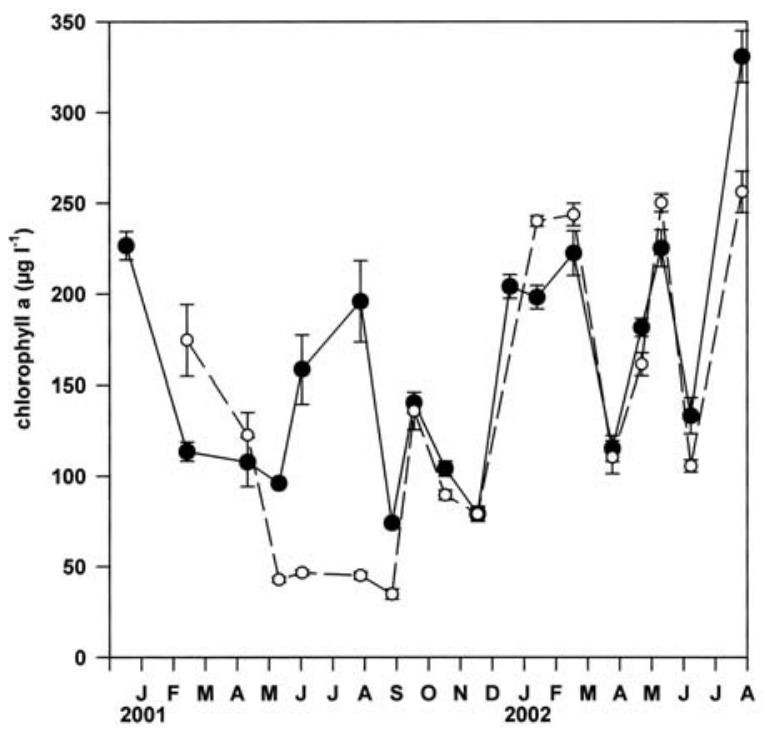

Figure 2. Concentration of planktonic chlorophyll $a$ in the surface (solid line) and bottom water (dashed line) at the open site during the study period. Mean $\pm \mathrm{SD}$. Concentración de clorofila a planctónica en la superficie (línea continua) y el fondo (linea discontinua) del centro durante el período de estudio.

$\mathrm{pH}$ of the surface water was always equal to or higher than the $\mathrm{pH}$ of the bottom water (Table 1). The layer of anoxic water in the open site was located at 2-2.5 $\mathrm{m}$ deep in spring-summer. In contrast, the bottom water at the littoral site was rarely anoxic (except in March 2002).

The light compensation depth in the open site ranged from 0.7 to $2.3 \mathrm{~m}$. Then, the availability of PAR in the bottom water was always lower than $1 \%$ during the study period. The light compensation depth was inversely correlated with the mean value of chlorophyll $a$ concentration in the water column $(\mathrm{r}=-0.581, \mathrm{P}<0.05)$ and also, with both the mean values of total suspended matter and organic suspended matter $(r=-0.718$, $\mathrm{r}=-0746, \mathrm{P}<0.01$, respectively). The concentration of planktonic chlorophyll $a$ ranged from 74.2 to $330.7 \mu \mathrm{g}^{-1}$ in the surface water and from 34.8 to $256.2 \mu \mathrm{g}^{-1}$ in the bottom water during the study period (Table 1). The concentration of planktonic chlorophyll $a$ was significantly higher in the surface than in the bottom water (Fig. 2) during June-September 2001 and July-August 2002 (t-student, $\mathrm{P}<0.01$ ).

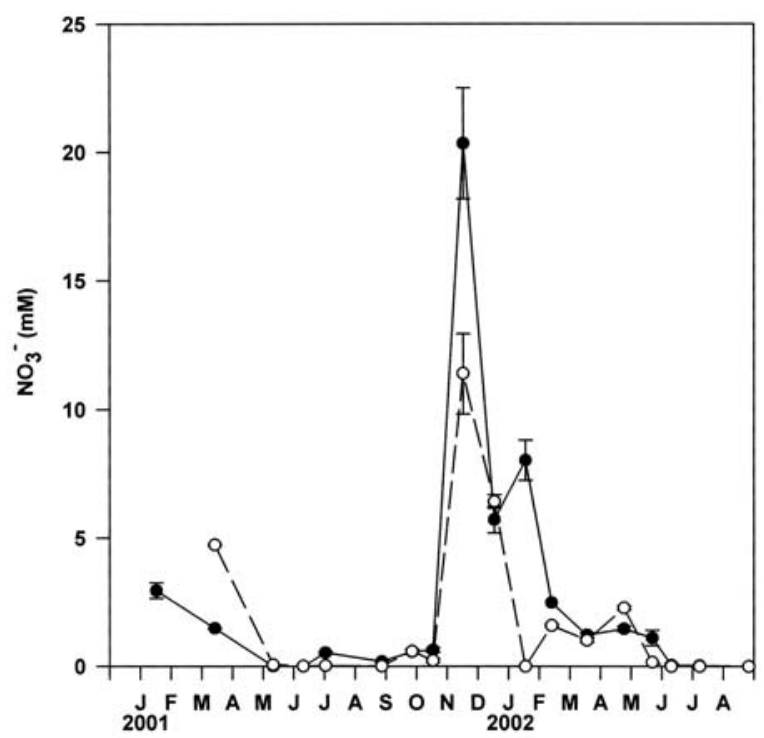

Figure 3. Concentration of $\mathrm{NO}_{3}^{-}$in the surface (solid line) and bottom water (dashed line) at the open site during the study period. Mean $\pm \mathrm{SD}$. Concentración de $\mathrm{NO}_{3}{ }^{-}$en la superficie (linea continua) y el fondo (línea discontinua) del centro durante el período de estudio.

The concentration of dissolved inorganic $\mathrm{N}$ followed a seasonal pattern, especially $\mathrm{NO}_{3}{ }^{-}$and $\mathrm{NO}_{2}{ }^{-}$concentrations that decreased in summer and increased during rainy periods (Fig. 3). In fact, the concentration of $\mathrm{NO}_{3}{ }^{-}$in the bottom water was significantly correlated to the amount of rainfall collected between samplings $(\mathrm{r}=0.717, \mathrm{P}<0.01)$. Also, both the $\mathrm{NO}_{2}{ }^{-}$concentration in the bottom and surface water were significantly correlated to rainfall $(\mathrm{r}=0.592$ and $\mathrm{r}=0.604 \mathrm{P}<0.05$, respectively). In contrast, the concentration of o-P in the water, especially in the bottom water, oscillated in pulses throughout the study period (Fig. 4). The concentration of o$\mathrm{P}$ in the interstitial water of the sediment also peaked intermittently and it was positively correlated with the concentration of o-P in the bottom-water $(\mathrm{r}=0.698, \mathrm{P}<0.05)$. The low availability of $\mathrm{P}$ and the high concentration of dissolved inorganic nitrogen (DIN) determined that the ratio of DIN/Tot-P was relatively large in both the surface and the bottom water (Table 1). In contrast, the ratio $\mathrm{N} / \mathrm{P}$ in the sediment ranged from 0.05 to 4.34 during the study period. 


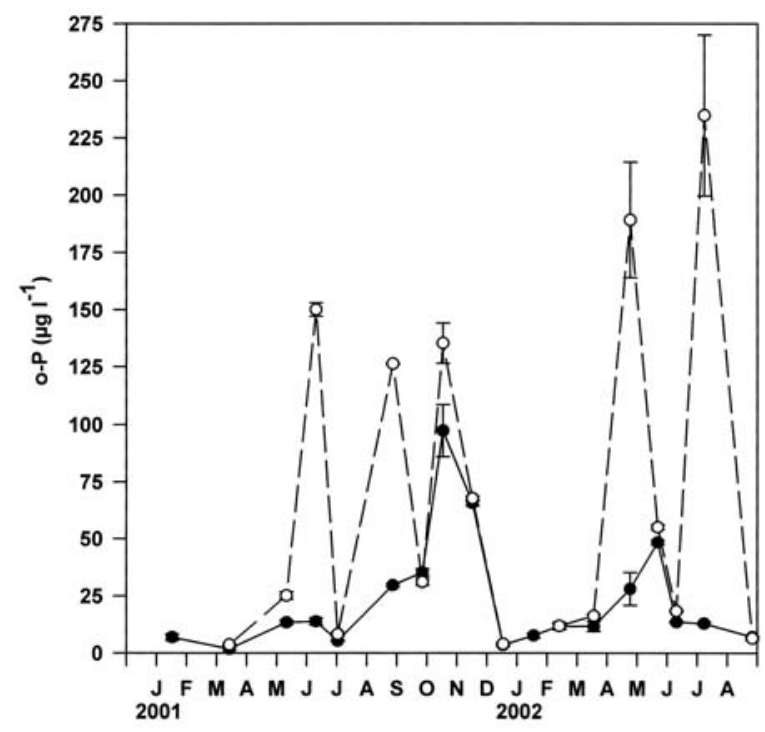

Figure 4. Concentration of o-P in the surface (solid line) and bottom water (dashed line) at the open site during the study period. Mean $\pm \mathrm{SD}$. Concentración de o-P en la superficie (linea continua) y el fondo (linea discontinua) del centro durante el periodo de estudio.

The concentration of Tot-P in the sediment ranged from 120.3 to $964.3 \mu \mathrm{gDW}^{-1}$, and the concentration of organic matter ranged from 0.9 to $13.5 \%$. Both variables were highly correlated $(\mathrm{r}=0.853, \mathrm{P}<0.01)$ suggesting that the sediment was rich in organic P-compounds. The P-fractionation of the sediment showed that the organic P-fractions comprised $75 \%$ of the fine sediment and $64 \%$ of the total sediment (Table 2). The largest P-fraction was always the one extracted with alkali (org- $\mathrm{P}_{\text {alkali }}$ ), followed by the acid soluble organic $\mathrm{P}$-fraction (org- $\mathrm{P}_{\text {acid }}$ ) in the fine sediment or the iron-bound fraction $(\mathrm{Fe}(\mathrm{OOH}) \sim \mathrm{P})$ in the total sediment. The org$\mathrm{P}_{\mathrm{acid}}$ and the residual organic fraction (org$\left.\mathrm{P}_{\text {residual }}\right)$ were higher in the fine sediment that in the total sediment ( $\mathrm{t}$-student, $\mathrm{P}<0.01$ ), whereas the $\mathrm{Fe}(\mathrm{OOH}) \sim \mathrm{P}$ and $\mathrm{CaCO}_{3} \sim \mathrm{P}$ were higher in the total sediment ( $\mathrm{t}$-student, $\mathrm{P}<0.01$ ). These differences can be explained by a lower content of large detrital particles in the fine sediment.

Fifty-five taxa of phytoplankton were identified during the study period: 25 taxa of cyanobacteria, 14 chlorophytes, 4 dinoflagelates, 10 diatoms, 3 cryptophytes and 3 chrysophytes (Table 3 ). The phytoplankton density ranged from $2 \cdot 10^{4}$ to $7 \cdot 10^{6}$ cells $\mathrm{ml}^{-1}$. Two taxa of cyanobacteria, Aphanocapsa holsatica and Microcystis sp., appeared with an average relative abundance of $35 \%$ and $30 \%$, respectively. Other taxa such as Cryptomonas sp., Amphidinium sp., Gymnodinium sp., Chaetosceros sp., Oocystis sp. and Pseudochorella sp., reached an average relative abundance of only $2.5-4 \%$. The most common taxa in all samplings (occurrence $>60 \%$ ) were Oscillatoria sp., Oocystis sp., Oscillatoria limnetica, Chroococcus sp. and Monoraphidium circinale (Table 3). Consequently, the diversity of phytoplankton was very low: an assemblage of just one, two or three taxa dominated with a relative abundance $>80 \%$ in most of the samplings.

The seasonal phytoplankton succession was different in both years of study. In 2001, the blooms of cyanobacteria (Oscillatoria sp., Microcystis sp.,) alternated with a high density of dinoflagellates (Amphidinium sp., Gymnodinium sp.), chlorophytes (Oocystis sp., Monoraphidium sp.) and diatoms (Chaetoceros sp.). However in 2002, cyanobacteria largely dominated for the most part of the year while the density of dinoflagellates and diatoms was greatly reduced (Fig. 5).

The high water turbidity hindered the growth of submersed aquatic macrophytes as only Potamogeton pectinatus grew in the shallower areas, while the littoral vegetation was mainly

Table 2. Concentration of o-P $\left(\mathrm{mg} \mathrm{gDW}^{-1}\right)$ in the different P-fractions of the fine sediment $(<0.1 \mathrm{~mm})$ and the total sediment in May 2001. Mean $\pm \mathrm{SD}$. Concentración de o-P $\left(\mathrm{mg} g \mathrm{gW}^{-1}\right)$ en las distintas fracciones de P en el sedimento fino y el sedimento total de mayo 2001.

\begin{tabular}{|c|c|c|c|c|c|}
\hline & $\mathrm{Fe}(\mathrm{OOH}) \sim \mathrm{P}$ & $\mathrm{CaCO}_{3} \sim \mathrm{P}$ & org- $\mathbf{P}_{\text {acid }}$ & org-P $P_{\text {alkali }}$ & org- $P_{\text {residual }}$ \\
\hline Fine sediment & $99 \pm 2.6$ & $110 \pm 22.3$ & $209 \pm 23.7$ & $364 \pm 34.8$ & $52 \pm 8.4$ \\
\hline Total sediment & $123 \pm 11.8$ & $222 \pm 8.5$ & $101 \pm 3.3$ & $495 \pm 30.6$ & $22 \pm 4.9$ \\
\hline
\end{tabular}




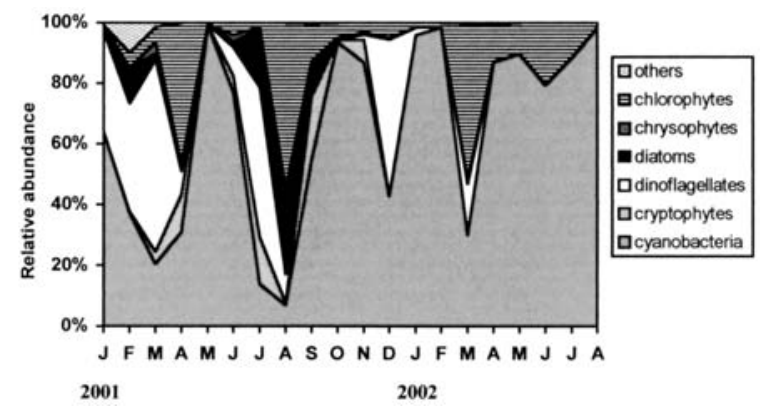

Figure 5. Changes in the relative abundance of phytoplankton composition in the surface at the open site during the study period. Cambios en la abundancia relativa de la composición fitoplanctónica en la superficie a lo largo del periodo de estu- composed of Phragmites australis and Typha latifolia. A few aquatic invertebrate species were recorded during the study period (Table 4). Only 5 rotifer species and 2 crustacean species were identified in the zooplankton. The total density of the zooplankton generally ranged between 100 and 2000 ind $1^{-1}$, but population explosions were common in rotifer species such

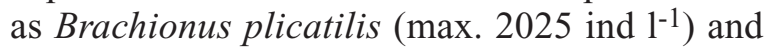
Keratella tropica (max. 2118 ind $\left.\mathrm{1}^{-1}\right)$. The minimum value of zooplankton density $\left(6\right.$ ind $\left.\mathrm{l}^{-1}\right)$ was recorded in June 2001 when the whole water column became anoxic.

Table 3. Average relative abundance (Fr.) and occurrence (Occ.) of main phytoplankton species during the study period. Promedio de la abundancia relativa $(\mathrm{Fr})$ y frecuencia de aparición (Occ.) de las principales especies del fitoplancton.

\begin{tabular}{|c|c|c|c|c|c|}
\hline Species & Fr. $(\%)$ & Occ. $(\%)$ & Species & Fr. (\%) & Occ. $(\%)$ \\
\hline CYANOBACTERIA & & & DIATOMS & & \\
\hline Anabaena aff. aspera & 0.1 & 13.6 & Amphora sp. & 0.1 & 13.6 \\
\hline Anabaena aff. spiroides & 1.6 & 31.8 & Cyclotella meneghiniana & 0.5 & 54.5 \\
\hline Anabaena aphanizomenoides & 0.4 & 27.3 & Cymbella sp. & 0.1 & 4.5 \\
\hline Anabaena sp.1 & 0.1 & 13.6 & Chaetosceros sp. & 3.9 & 45.4 \\
\hline Anabaena sp.2 & 0.1 & 9.1 & Fragillaria aff. construens & $<0.1$ & 4.5 \\
\hline Anabaenopsis circularis & 0.1 & 9.1 & Melosira sp. & 0.1 & 9.1 \\
\hline Anabaenopsis sp. & 0.1 & 4.5 & Nitzschia palea & 0.1 & 4.5 \\
\hline Aphanocapsa holsatica & 35.4 & 22.7 & Nitzschia sp. & 0.1 & 9.1 \\
\hline Aphanocapsa incerta & 1.0 & 9.1 & Unidentified pennate diatom & 0.2 & 9.1 \\
\hline Caelosphaerium sp. & 1.3 & 22.7 & CHRYSOPHYTES & & \\
\hline Calothrix sp. & 0.1 & 4.5 & Mallomonas sp & $<0.1$ & 4.5 \\
\hline Chlrogloea sp. & 0.1 & 4.5 & Ochromonas sp. & 0.1 & 18.2 \\
\hline Chroococcus aff. dispersus & 3.0 & 27.3 & Unidentified chrysophyta & 0.1 & 4.5 \\
\hline Chroococcus sp. & 0.8 & 63.6 & CHLOROPHYTES & & \\
\hline Gomphosphaeria sp. & 0.3 & 4.5 & Ankistrodesmus sp. & 0.1 & 4.5 \\
\hline Lynbya sp. & 0.1 & 18.2 & Coelastrum sp. & 0.1 & 9.1 \\
\hline Merismopedia sp. & 0.1 & 9.1 & Chlamydomonas sp. & 0.1 & 4.5 \\
\hline Microcystis sp. & 30.0 & 54.5 & Chlorella sp. & 0.9 & 13.6 \\
\hline Oscillatoria limnetica & 1.4 & 63.6 & Monoraphidium circinale & 1.0 & 63.6 \\
\hline Oscillatoria sp. & 0.4 & 77.3 & Monoraphidium contortum & 0.3 & 36.4 \\
\hline Spirulina sp. & 0.1 & 18.2 & Oocystis sp. & 3.4 & 72.7 \\
\hline Synechococcus sp. & 0.1 & 13.6 & Pandorina sp. & 0.1 & 4.5 \\
\hline Synechocystis sp. & 0.5 & 9.1 & Piramidomonas sp. & $<0.1$ & 4.5 \\
\hline CRYTOPHYTES & & & Pseudochlorella sp. & 3.1 & 4.5 \\
\hline Cryptomonas sp. 1 & 3.5 & 59.1 & Scenedesmus sp. & $<0.1$ & 4.5 \\
\hline Cryptomonas sp.2 & 0.1 & 27.3 & Schroederia sp. & 0.1 & 40.9 \\
\hline Chroomonas aff. acuta & 0.1 & 9.1 & Unidentified Chlorococcal & 0.8 & 54.5 \\
\hline DINOFLAGELLATES & & & Unidentified Volvocal & 0.1 & 9.1 \\
\hline Amphidinium sp. & 3.2 & 40.9 & & & \\
\hline Glenodinium sp. & 0.1 & 9.1 & & & \\
\hline Gymnodinium sp. & 2.6 & 50.0 & & & \\
\hline Gymnodinium sp.2 & 0.1 & 9.1 & & & \\
\hline
\end{tabular}


Table 4. List of aquatic microinvertebrate species. Lista de microinvertebrados acuáticos.

\section{ROTIFERA}

Brachionus plicatilis

B. calyciflorus

B. novae-zelandiae

Keratella tropica

Testudinella patina

CLADOCERA

Daphnia longispina

COPEPODA

Acanthocyclops cf. kieferi

ISOPODA

Sphaeroma serratum

GASTROPODA

Physella acuta

Potamopyrgus antipodarum

DIPTERA

Chironomus plumosus

The relative abundance of Chironomus plumosus increased in autumn-winter (347-15000 ind $\mathrm{m}^{-2}$ in the open-site and 521-31900 ind $\mathrm{m}^{-2}$ in the littoral site) and decreased in spring-summer (0-140 ind $\mathrm{m}^{-2}$ in the open-site and 0-1945 ind $\mathrm{m}^{-2}$ in the littoral site), reaching zero during June-July 2001 (open site) and June-August 2002 (both littoral and open sites).

\section{DISCUSSION}

Due to its artificial origin as an extractive pit, the surface basin of the lagoon is limited to its shoreline so it is basically fed by ground water and direct rainfall. The importance of ground water feeding is supported by the increase in conductivity during rainy periods. The salinity of the riverbed aquifer of the Guadalquivir River is very high in this area due to a fossil aquifer below the estuary (IGME, 1975) and to the partial intrusion of seawater (Navarro Alvargonzález et al., 1993). Additionally, the high ratio of $\mathrm{Cl}^{-}$: $\mathrm{SO}_{4}^{-}$, and the relation of $\mathrm{Cl}^{-}>\mathrm{SO}_{4}{ }^{2-}>\mathrm{CO}_{3} \mathrm{H}^{-}$in hyperhaline waters is typical of coastal lagoons (Alonso, 1998). Although the surface of the Tarelo lagoon is not connected to the estuary, seawater can influence the ionic composition of the lagoon through both ground water seepage and spray.

The high concentrations of both $\mathrm{NO}_{3}{ }^{-}$and $\mathrm{NO}_{2}^{-}$in the water and their positive correlation to rainfall is also an indication of the importance of ground water feeding in this lagoon. The ground water of the Guadalquivir riverbed is polluted with $\mathrm{N}$ as high $\mathrm{NO}_{3}{ }^{-}$concentrations (ca. $8 \mathrm{mM}$ ) were already detected in this area in 1987 (Navarro Alvargonzález et al., 1993). The amount of $\mathrm{NO}_{3}{ }^{-}$recorded in this lagoon (up to $20.3 \mathrm{mM}$ ) was even larger than that found in the eutrophic lagoons of Adra which received the direct inlet of agricultural runoff (Carrillo et al., 1996). In contrast, $\mathrm{NO}_{2}^{-}$tended to be very low and $\mathrm{NH}_{4}{ }^{+}$was the dominant inorganic form of $\mathrm{N}$ in other aquatic environments of the Doñana area such as the temporary ponds on aeolian sand (Serrano \& Toja, 1995). The load of $\mathrm{NO}_{3}{ }^{-}$ and $\mathrm{NO}_{2}^{-}$during rainy periods declined abruptly during both summers when $\mathrm{NO}_{3}{ }^{-}$concentration reached zero in the bottom water of this lagoon. The total concentration of DIN also decreased during both summers and was minimal in June 2001. Therefore, DIN showed a seasonal pattern of enrichment in autumn-winter due to ground water seepage, and of decline in summer due to both denitrification and $\mathrm{NO}_{3}{ }^{-}$assimilation.

In spite of the mixing created by the frequent coastal winds, significant differences between the surface and the bottom of the water column were detected, particularly in summer, in relation to several limnological variables, such as the concentration of phytoplankton, dissolved oxygen, $\mathrm{pH}$, and suspended solids. Thus, both the spatial and temporal variability of those variables related to the primary production were coupled in a seasonal pattern of vertical segregation. The abrupt extinction of the light penetration and the different availability of nutrients in the water column can account for this pattern.

In contrast to the seasonal pattern of $\mathrm{N}$, the dynamics of $\mathrm{P}$ fluctuated in pulses. The concentration of o-P in both the bottom water and the interstitial water peaked during periods of anoxia in the deep water. There are three hypothesis to explain the release of o-P from anoxic sedi- 
ments: through the reduction of $\mathrm{Fe}(\mathrm{OOH}) \sim \mathrm{P}$, the acidification of sediments, and the mineralization of organic P-compounds such as phytate (Golterman et al., 1998). The decomposition of organic matter in the sediment is a simple mechanism of o-P release that cannot be ruled out (Prairie et al.,2002), especially in this case, when Tot-P and organic matter in the sediment are highly correlated. The concentration of Tot-P in the sediment of this lagoon fell within the range of other eutrophic shallow systems such as the coastal lagoons of Adra (De Vicente et al., 2003) and the Doñana temporary ponds (DíazEspejo et al., 1999). The majority of the Tot-P in the sediment of this lagoon was composed of organic P-fractions as in the case of the Doñana ponds (Díaz-Espejo et al., 1999; Serrano et al., 2000) where Tot-P and sediment organic matter were also correlated (Jaúregui \& Toja, 1993). Therefore, the eutrophic state of this lagoon ensured a high internal P-loading as the concentration of planktonic chlorophyll $a$ in the water column averaged $137.5 \mu \mathrm{g} \mathrm{l}^{-1}$ during the study period. An even higher concentration of chlorophyll $a$ has been recorded in the hypereutrophic coastal lagoon Albufera of Valencia (200-600 $\mu \mathrm{g}^{-1}$ ) that was also dominated by cyanobacteria (Vicente \& Miracle, 1992).

The variability of the local wind speed can also generate pulse-scale events that may produce a significant effect on the functioning of the system under the present conditions of high phytoplankton production. This is the case of an episode of anoxia, on $12^{\text {th }}$ June 2001 , that depleted the entire water column of dissolved oxygen after a period of intermittent mixing generated by an alternation of strong winds and calms. During intermittent mixing, cyanobacteria, such as Microcystis colonies, migrate upward bringing about the development of blooms (Easthope \& Howard, 1999). In fact, Microcystis bloomed in this lagoon in May 2001 resulting in the minimum value of light penetration in 2001 and the highest value of tot$\mathrm{P}$ in the particulate suspended material of both the surface and the bottom water. One month later, the episodic anoxia took place and the water column became distinctly segregated in two layers: a surface layer with more chlorophyll $a$ and less o-P than the bottom layer. The availability of nutrients in a dim light environment could have favoured the later growth of Oscillatoria. It is well known the ability of cyanobacteria to alternate between autotrophic and heterotrophic metabolisms and, in particular of Oscillatoria limnetica, to alternate between oxygenic and a non-oxygenic photosynthesis when the sulphide concentration is high and the available PAR is low (Atlas \& Bartha, 1998). Some algal species are also able to turn to a heterotrophic metabolism when light availability is very low and there is a high pool of dissolved organic compounds derived from the dying cells (Tuchman, 1996; Sorokin, 1999). That is the case of the dinoflagellate Gymnodinium and the diatom Chaetoceros that bloomed in July and August 2001, respectively. In the long run, cyanobacteria are known to dominate the phytoplankton community in eutrophic systems due to the many advantages they can exhibit under fluctuating conditions, such as their metabolic versatility, their gas vesicles, their nutrient uptake at very low o-P concentration and their capacity to thrive in reducing conditions (Sorokin, 1999). In this lagoon, the intermittent mixing, the different time-scales of nutrient availability, the variability of the underwater light environment and of the reducing conditions, created a fluctuating environment most suitable for cyanobacteria.

As it can be expected in eutrophic systems under stress, the number of taxa was relatively low and the communities were dominated by only a few species. Similarly, more than $80 \%$ of the total phytoplankton biomass was comprised by no more than three species during most part of the year in the hypereutrophic lagoon Albufera of Valencia (Romo \& Miracle, 1995). Even an opportunistic species, such as Chironomus plumosus, common in eutrophic environments (Prat, 1991) disappeared from the sediment surface during summer. Similarly, an indicator of both eutrophic and mineralised waters such as Potamogeton pectinatus 
(Scheffer, 1998) was very scarce and restricted to the shallower areas.

Although the study period was to short to draw any tendency, there were some indications of a quick progress towards an even higher trophic degree: the concentration of both total and organic suspended matter increased in 2002 with respect to 2001 and the average summer chlorophyll was also higher in 2002 as well as the relative abundance of cyanobacteria. A tendency towards a more advanced stage of eutrophication is quiet likely as eutrophic environments dominated by cyanobacteria can create a self-regulated system to maintain stable blooms in lakes (Sakamoto \& Okino, 2000; Gibson et al., 2000). However in the context of coastal lagoons, transitional stages can also lead to unstable situations (Comín et al., 1999). After years without apparent changes, catastrophic shifts have drastically changed the aquatic communities of the coastal lagoon Albufera of Valencia (Vicente \& Miracle, 1992). The coastal lagoons of Comacchio (Italy) have reached a precarious equilibrium under the absolute dominance of cyanobacteria with the alternation of autotrophic and heterotrophic stages when the aquatic fauna crashes to undetectable numbers during dystrophic crisis (Sorokin, 1999). Therefore, as primary production increases in the lagoon of Tarelo, the food available for the White-headed duck (Oxyura leucocephala) will likely decrease as this species feeds mainly on chironomids, and secondary on aquatic submersed macrophytes (Green et al., 1999).

\section{ACKNOWLEDGEMENTS}

We thank Jose Maria Arana for his help and patience, and Luis Rodriguez "Fon" for his collaboration. We are also thankful to the rangers of the Doñana Natural Park, to Sra. Lola and her family, to the people of Venta El Raspa and Casa Rural La Algaida. The Consejería de Medio Ambiente, Junta De Andalucía, supported this project.

\section{REFERENCES}

ALONSO, M. 1998. Las lagunas de la España peninsular. Limnetica, 15: 1-176.

APHA. 1985. Standard methods for the examination of water and wastewater. $16^{\text {th }} \mathrm{ed}$. American Public Health Association.

ATLAS, R. M. \& R. BARTHA. 1998. Microbial Ecology. Fundamentals and applications. Benjamin/Cummings Publishing Company, Inc. Menlo Park, 694 pp.

CARRILLO, P., P. SÁNCHEZ-CASTILLO, L. CRUZ-PIZARRO \& R. MORALES. 1996. Cambios cíclicos y tendencias a largo plazo en la salinización de ecosistemas fluctuantes (Albuferas de Adra). Evidencias de eutrofización y contaminación. Limnetica, 12: 59-65.

COMÍN, F. A, F. MENÉNDEZ, J. A. ROMERO, O. HERNÁNDEZ, M. MARTÍNEZ \& A. CHACÓN. 1999. Indicadores ecológicos y herrramientas para la gestión de ecosistemas acuáticos en la zona costera. Limnetica, 16: 61-68.

DE GROOT, K. J. \& H. L. GOLTERMAN. 1990. Sequential fractionation of sediment phosphate. Hydrobiologia, 192: 143-149.

DE VICENTE, I., L. SERRANO, V. AMORES, V. CLAVERO \& L. CRUZ-PIZARRO. 2003. Sediment phosphate fractionation and interstitial water phosphate concentration in two coastal lagoons (Albuferas de Adra, SE Spain). Hydrobiologia, 492: 95-101.

DÍAZ-ESPEJO, A., L. SERRANO \& J. TOJA. 1999. Changes in sediment phosphate composition of seasonal ponds during filling. Hydrobiologia, 392: 21-28.

GIBSON, C. E., R. H. FOY \& S. D. LENNOX. 2002. The rise and rise of Planktothrix agardhii in Lough Neagh 1969-1997. Verh. Internat. Verein. Limnol., 27: 2913-2916.

GREEN, A. J., A. D. FOX, B. HUGHES \& G. M. HILTON. 1999. Time-activity budgets and site selection of White-headed Ducks Oxyura leucocephala at Burdur Lake, Turkey in late winter. Bird Study, 46: 62-73.

GOLTERMAN, H. L. 1991. Direct nesslerization of ammonia and nitrate in fresh-water. Annls Limnol., 27: 99-101.

GOLTERMAN, H. L. 1996. Fractionation of sediment phosphate with chelating compounds: a simplification, and comparison with other methods. Hydrobiologia, 335: 87-95. 
GOLTERMAN, H. L., R. S. CLYMO. \& M. A. M. OHUSTAD. 1978. Methods for physical and chemical analysis of freshwater. IBP Handbook 8, Blackwell Scientific Publications, Oxford.

GOLTERMAN, H. L., J. PALLING, L. SERRANO \& E. GÓMEZ. 1998. Presence of and phosphate release from polyphosphates or phytate phosphate in lake sediments. Hydrobiologia, 364: 99-104.

I.G.M.E. 1975. Mapa Geológico de España, 1: 50 000. Servicio de Publicaciones. Ministerio de Industria. Madrid.

EASTHOPE, M. P. \& A. HOWARD. 1999. Implementation and sensitivity analysis of a model of Cyanobacterial movement and growth. Hydrobiologia, 414: 53-58.

JAUUREGUI, J. \& J. TOJA. 1993. Dinámica del fósforo en lagunas temporales del P.N.de Doñana. In: Actas VI Congreso Español de Limnología. L. Cruz-Pizarro et al. (eds.). Granada (Spain). 99106.

MARGALEF, R. 1983. Limnología. Ed. Omega. Barcelona. 1010 pp.

MARKER, A. F. H., HUSCH, E. A., H. R. TAI \& B. RIEMANN. 1980. The measurement of photosynthetic pigments in freshwaters and standarization of methods: conclusions and recommendations. Arch. Hydrobiol. Beih., 14: 91-106.

MURPHY, J. \& J. P. RILEY. 1962. A modified single solution method for the determination of soluble phosphate in natural waters. Analitycal Chemical Acta, 27: 31-36.

NAVARRO ALVARGONZÁlEZ, A., A. FERNÁNDEZ URÍA \& J. G. DOBLAS DOMÍNGUEZ. 1993. Las aguas subterráneas en España. Estudio de sintesis. Instituto Tecnológico Geominero de España.

PRAIRIE, Y. T., C. DE MONTIGNY \& P. DEL GIORGIO. 1998. Phosphorus release from anoxic sediments: Mortimer's paradigm revisited. Verh. Internat. Verein. Limnol., 27: 4013-4021.
PRAT, N., F. SANZ \& E. MARTÍNEZ-ANSEMIL. 1991. El bentos profundo y litoral de una cadena de tres embalses españoles del río Guadiana ( $\mathrm{SW}$ España). Limnetica, 7: 133-152.

RODIER, J. 1981. Análisis de aguas. Ed. Omega. Barcelona.

ROMO, S. \& M. R. MIRACLE. 1995. Diversity of the phytoplankton assemblages of a polymictic hypertrophic lake. Arch. Hydrobiol., 132: 363-384.

SAKAMOTO, M. \& T. OKINO. 2000. Self-regulation of cyanobacterial blooms in a eutrophic lake. Verh. Internat. Verein. Limnol., 27: 1243-1249.

SCHEFFER, M. 1998. The ecology of shallow lakes. Chapman \& Hall. London. 357 pp.

SERRANO, L. \& J. TOJA. 1995. Limnological description of four temporary ponds in the Doñana National Park (SW Spain). Archiv für Hydrobiologie, 133: 497-516.

SERRANO, L., M. REINA, E. DE VERD, J. TOJA \& H. L. GOLTERMAN. 2000. Determination of the sediment phosphate composition by the EDTA method of fractionation. Limnetica, 19: 199-204.

SOROKIN, Y. I. 1999. Aquatic Microbial Ecology. Backhuys Publishers. Leiden, 248 pp.

STRICKLAND, J. D. \& T. R. PARSONS. 1972. A practical handbook of seawater analyses. Fish. Res. Bd. Can. Bull.,167 pp.

TUCHMAN, N. 1998. The role of heterotrophy in algae. In: Algal Benthic Ecology. R. J. Stevenson, M.L. Bowell \& R.L. Lowe (eds.). Academic Press. San Diego, 753, pp.

UTERMÖHL, H. 1958. Zur Vervolkommnung der quantitativen Phytoplankton-Methodik. Mitt. Int. Verein. Limnol., 9: 1-38.

VICENTE, E. \& M. R. MIRACLE. 1992. The coastal lagoon Albufera de Valencia: an ecosystem under stress. Limnetica, 8: 87-100.

VOLLENWEIDER, R. A. 1969. Primary production in aquatic environments. IBP Handbook 12. Blackwell Scientific Publications. 